Atmos. Chem. Phys., 10, 2867-2877, 2010

www.atmos-chem-phys.net/10/2867/2010/

(C) Author(s) 2010. This work is distributed under

the Creative Commons Attribution 3.0 License.

\title{
The organic fraction of bubble-generated, accumulation mode Sea Spray Aerosol (SSA)
}

\author{
R. L. Modini, B. Harris, and Z. D. Ristovski \\ ILAQH, Queensland University of Technology, P.O. Box 4233, Brisbane QLD, 4001, Australia \\ Received: 14 September 2009 - Published in Atmos. Chem. Phys. Discuss.: 12 October 2009 \\ Revised: 20 January 2010 - Accepted: 22 March 2010 - Published: 26 March 2010
}

\begin{abstract}
Recent studies have detected a dominant accumulation mode $(\sim 100 \mathrm{~nm})$ in the Sea Spray Aerosol (SSA) number distribution. There is evidence to suggest that particles in this mode are composed primarily of organics. To investigate this hypothesis we conducted experiments on $\mathrm{NaCl}$, artificial SSA and natural SSA particles with a Volatility-Hygroscopicity-Tandem-DifferentialMobility-Analyser (VH-TDMA). $\mathrm{NaCl}$ particles were atomiser generated and a bubble generator was constructed to produce artificial and natural SSA particles. Natural seawater samples for use in the bubble generator were collected from biologically active, terrestrially-affected coastal water in Moreton Bay, Australia. Differences in the VH-TDMAmeasured volatility curves of artificial and natural SSA particles were used to investigate and quantify the organic fraction of natural SSA particles. Hygroscopic Growth Factor (HGF) data, also obtained by the VH-TDMA, were used to confirm the conclusions drawn from the volatility data. Both datasets indicated that the organic fraction of our natural SSA particles evaporated in the VH-TDMA over the temperature range $170-200^{\circ} \mathrm{C}$. The organic volume fraction for $71-77 \mathrm{~nm}$ natural SSA particles was $8 \pm 6 \%$. Organic volume fraction did not vary significantly with varying water residence time $(40 \mathrm{~s}$ to $24 \mathrm{~h}$ ) in the bubble generator or SSA particle diameter in the range $38-173 \mathrm{~nm}$. At room temperature we measured shape- and Kelvin-corrected HGF at $90 \%$ RH of $2.46 \pm 0.02$ for $\mathrm{NaCl}, 2.35 \pm 0.02$ for artifical SSA and $2.26 \pm 0.02$ for natural SSA particles. Overall, these results suggest that the natural accumulation mode SSA particles produced in these experiments contained only a minor organic fraction, which had little effect on hygroscopic growth. Our measurement
\end{abstract}

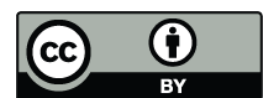

Correspondence to: Z. D. Ristovski (z.ristovski@qut.edu.au) of $8 \pm 6 \%$ is an order of magnitude below two previous measurements of the organic fraction in SSA particles of comparable sizes. We stress that our results were obtained using coastal seawater and they can't necessarily be applied on a regional or global ocean scale. Nevertheless, considering the order of magnitude discrepancy between this and previous studies, further research with independent measurement techniques and a variety of different seawaters is required to better quantify how much organic material is present in accumulation mode SSA.

\section{Introduction}

Sea Spray Aerosol (SSA) is generated when air bubbles rise to the ocean surface and burst or when seawater droplets are torn from the crests of waves. These seemingly simple processes create the largest mass emission flux to the atmosphere of all aerosol types (Andreae and Rosenfield, 2008). SSA particles vary in size over 5 decades from tens of nanometres to hundreds of micrometres. Large supermicrometre SSA particles account for the majority of sea spray mass in the atmosphere ( $>95 \%)$. However it is the submicrometre SSA particles that are by far the most numerous. In particular recent laboratory and field measurements have consistently detected a dominant mode in the SSA number distribution centred at $100 \mathrm{~nm}$ dry diameter (Clarke et al., 2006; Martensson et al., 2003; O’Dowd and Smith, 1993; Sellegri et al., 2006; Tyree et al., 2007). In this study we will refer to this dominant mode as the SSA accumulation mode even though it extends to particle sizes traditionally placed in the Aitken mode $(20-100 \mathrm{~nm})$. The SSA accumulation mode is climatically very important because it means SSA can potentially account for a significant proportion of

Published by Copernicus Publications on behalf of the European Geosciences Union. 
cloud condensation nuclei $(\mathrm{CCN})$ in the remote marine environment, particularly under high wind conditions (Clarke et al., 2006; O'Dowd and Smith, 1997; Pierce and Adams, 2006).

Bursting bubbles produce SSA in the form of film drops and jet drops. The SSA accumulation mode most likely originates from film drops. These are generated when fragments of bubble film (cap) are ejected into the air as a bubble bursts. Secondary droplets created when some of these fragments collide with the air-water surface may also contribute to the SSA accumulation mode (Spiel, 1998). Milliseconds after a bubble burst (Spiel, 1995) jet drops are generated from the break-up of the upward moving jet column caused by the collapse of the bubble cavity. Jet drops are in the supermicrometre size range: they are roughly one tenth the size of their parent bubbles (Blanchard, 1989).

The composition of SSA is surprisingly complex. Seawater contains a range of inorganic salts (see Sect. 2.2) which all exist in SSA. In addition SSA contains an organic fraction which is derived from on or near the ocean surface. The existence of an organic fraction in SSA was detected many years ago (Blanchard, 1964). A number of studies found that the concentration of organic carbon (Gershey, 1983; Hoffman and Duce, 1976) and bacteria (e.g. see Blanchard, 1989 and references therein) in bulk SSA is enriched hundreds of time relative to corresponding concentrations in source water. Enrichment of organic matter in SSA occurs because it is generated from bubbles bursting in an enriched layer of chemical and biological material on seawater surfaces known as the sea-surface micro-layer (e.g. Liss and Duce, 1997). Organic material, and in particular surface-active organic material, becomes concentrated at the sea-surface micro-layer by factors of up to 10 compared to sub-surface waters (Hunter, 1997) due to processes such as diffusion, turbulent mixing and scavenging and transport by rising air bubbles.

Decades ago it was hypothesised that the organic fraction of SSA may increase with decreasing particle size (Barker et al., 1972; Hoffman and Duce, 1974). Three recent studies have examined this hypothesis. Oppo et al. (1999) constructed a simple model that predicted the surfactant organic fraction of SSA droplets will increase hyperbolic-like with decreasing droplet size. The model rests on the assumption that SSA droplets produced from the rough sea surface contain condensed, saturated films of surfactant material of constant thickness (independent of droplet size).

Experimentally, detailed measurements of the sizeresolved organic fraction of SSA produced by flowing natural seawaters through bubble generators were conducted by Facchini et al. (2008) and Keene et al. (2007). A bubble generator mimics the bubble bursting process on ocean surfaces to generate nascent SSA isolated from other aerosol types. Both of these studies employed size-resolved impactor sampling and subsequent chemical analysis to show that SSA organic fraction increased with decreasing particle size in their experiments. Both studies measured an organic mass frac- tion of $\sim 80 \%$ for the lowest stages of their impactor samples corresponding to aerodynamic diameters of $130 \mathrm{~nm}$ (GMD, Keene et al., 2007) and 125-250 nm (Facchini et al., 2008). However Keene et al. (2007) only measured soluble organics, and Facchini et al. (2008) measured both soluble and insoluble organics and found insoluble components dominate ( $\sim 94 \%$ of organics). While both studies had different operative definitions of solubility, this consideration still implies that the results of these separate experiments do not agree as well as they first appear to. Nevertheless, based on these studies it is currently expected that the accumulation mode of SSA produced from biologically active seawater consists of particles that are predominantly organic. Big and Leck (2008) go even further to suggest that the particles comprising the SSA accumulation mode $(<200 \mathrm{~nm})$ are actually organic fragments with no inorganic component at all.

It is important to characterise the composition of particles in the SSA accumulation mode to correctly model their climatic influence. The organic fraction of SSA particles will affect their size as a function of RH (Ming and Russell, 2001) and therefore their scattering potential (Randles et al., 2004), their ability to act as CCN (Moore et al., 2008) and also their role in atmospheric chemistry (Zhou et al., 2008). The purpose of this study was to investigate and quantify the organic fraction of bubble-chamber-generated accumulation mode SSA using an original, independent and on-line method: the Volatility Hygroscopicity-Tandem Differential Mobility Analyser (VH-TDMA). In addition the VH-TDMA was also able to measure the hygroscopic growth factors of SSA accumulation mode particles.

\section{Experimental methods}

\subsection{Bubble generator}

A bubble generator was constructed to mimic the production of SSA by bursting bubbles on seawater surfaces. The generator is depicted in Fig. 1. It consisted of a $1 \mathrm{~m}$ long glass cylinder ( $i d=2.9 \mathrm{~cm}$ ) with a fritted glass tip (SKC midget impinger; pore size $170-220 \mu \mathrm{m}$ ) inserted at the bottom. Sample water entered the bottom of the generator from a $20 \mathrm{~L}$ plastic drum. The $20 \mathrm{~L}$ drum was placed above the generator so that gravity was the driving force of water through the system. A tap was used to control the water flow rate. Water exited the generator through a $1 / 4$ inch plastic tube fitted with a valve to prevent external air entering the generator. The vertical position of the exit tube was used to set the height of water in the generator. In these experiments the height was set for a bubble-rise distance of $31 \mathrm{~cm}$. This corresponded to a water volume of $200 \mathrm{~mL}$. Particle-free air was bubbled through the fritted tip at a flow rate of $100 \mathrm{~mL} \mathrm{~min}^{-1}$ to produce a steady stream of bubbles. Bubble size distribution was not measured in these experiments. A sample outlet at the top of the generator was used to extract SSA produced by 


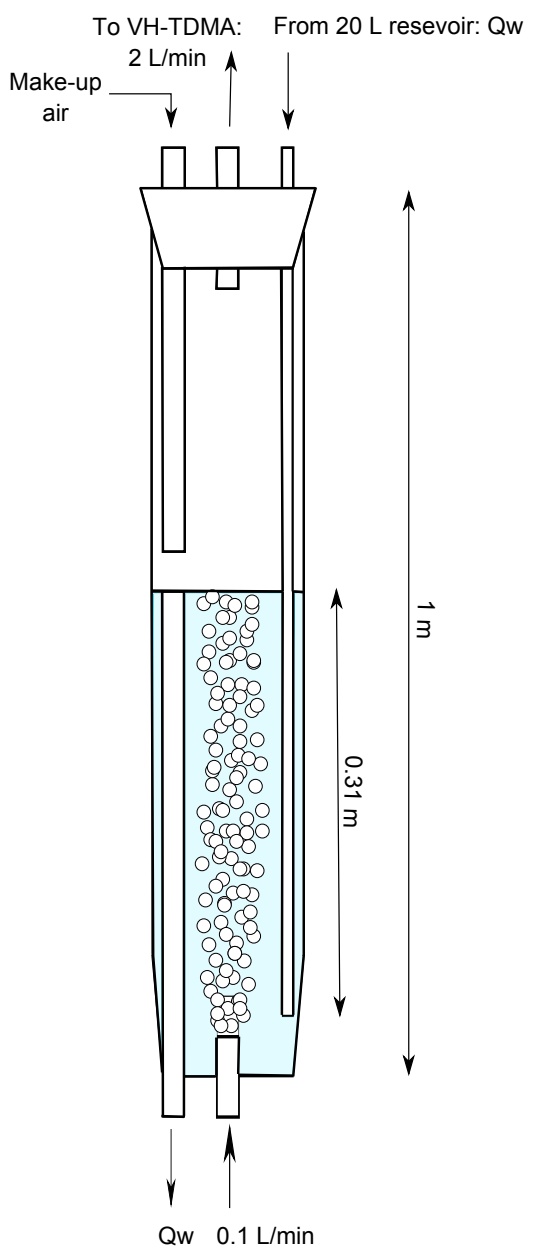

Fig. 1. A schematic diagram of the bubble generator used to produce sea spray aerosol (SSA). $Q_{w}$ is the water flow rate through the generator which was varied between experiments.

bursting bubbles at $2 \mathrm{~L} \mathrm{~min}^{-1}$ for VH-TDMA analysis. An inlet tube led from the top of the generator to just above the air-water interface to allow time for particle-free make-up air to mix with SSA before being sampled by the VH-TDMA. All experiments were conducted at room temperature $\left(25^{\circ} \mathrm{C}\right)$ and SSA was dried $(<10 \% \mathrm{RH})$ before it entered the $\mathrm{VH}-$ TDMA. The dry size distribution (9-379 nm) of SSA produced in our generator consisted of a dominant accumulation mode centred at $\sim 80 \mathrm{~nm}$ (Fig. 2), which compares well with other bubble-generated SSA size distributions (Martensson et al., 2003; Sellegri et al., 2006; Tyree et al., 2007).

\subsection{Sample water}

Experiments were conducted with two main types of water in the bubble generator: artificial sea salt solution (artificial SW) and natural seawater (natural SW). In addition the results were compared to VH-TDMA measurements of $\mathrm{NaCl}$ particles generated from an atomised solution of

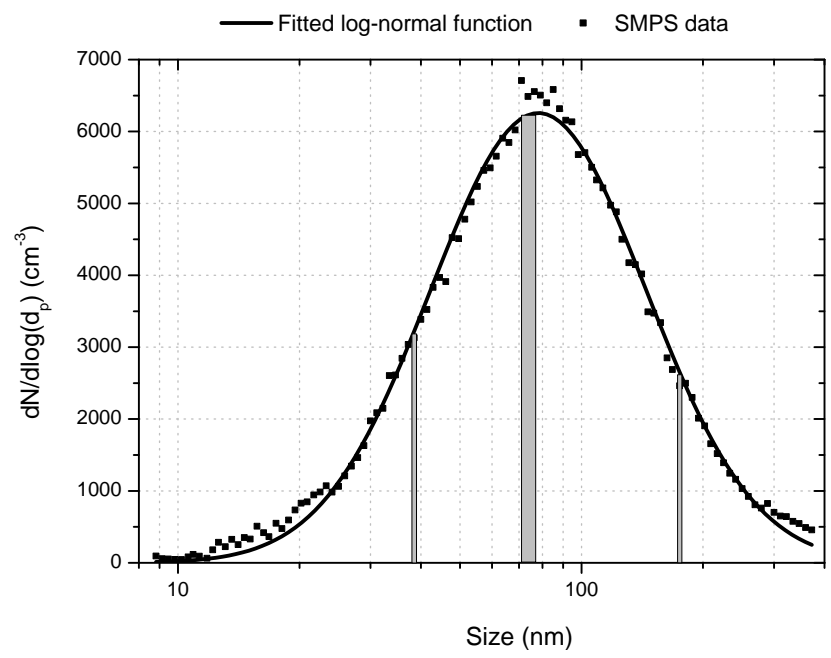

Fig. 2. An SMPS size distribution (9-379 nm) of dry SSA produced from natural seawater in our bubble generator. Grey rectangles indicate particle sizes that were selected for VH-TDMA analysis.

$\mathrm{NaCl}$ in ultra-pure deionised water. Artificial sea salt solution was generated by dissolving analytical grade sodium chloride $(\mathrm{NaCl})$, magnesium chloride $\left(\mathrm{MgCl}_{2}\right)$, sodium sulphate $\left(\mathrm{Na}_{2} \mathrm{SO}_{4}\right)$, calcium chloride $\left(\mathrm{CaCl}_{2}\right)$, potassium sulphate $\left(\mathrm{K}_{2} \mathrm{SO}_{4}\right)$, sodium bromide $(\mathrm{NaBr})$ and potassium nitrate $\left(\mathrm{KNO}_{3}\right)$ in ultra-pure deionised water. Two artificial salt solutions were prepared with varying ionic composition (Seinfeld and Pandis, 2006, p. 444; Niedermeier et al., 2008, Atlantic Ocean sample).

Natural SW was collected at high tide on 28 January 2009 from Redcliffe Jetty, which extends $200 \mathrm{~m}$ into the northwestern section of Moreton Bay on the east coast of Australia. Two minor river systems lie $11 \mathrm{~km}$ to the northwest (Caboolture River) and $8 \mathrm{~km}$ to the south-west (Pine River) of the sampling site. As such the sampling site is subject to significant terrestrial run-off. The salinity of the collected samples was $31.8 \mathrm{~g} \mathrm{~L}^{-1}$, measured via electrical conductivity (Eaton et al., 2005). The organic fraction or biological activity of our natural SW samples was not measured. However, monthly chlorophyll- $a$ (chl- $a$ ) measurements (absorbance spectroscopy) at three sampling sites within a $4 \mathrm{~km}$ radius of the sampling point were provided by the South East Queensland Healthy Waterways Partnership (www.healthywaterways.org). Chl- $a$ values at the three sites on 6-7 January 2009 varied between $1.47-3.14 \mathrm{mg} \mathrm{m}^{-3}$. On 5 or 19 February 2009 chl- $a$ values at the three sites were in the range $1.29-3.21 \mathrm{mg} \mathrm{m}^{-3}$. Therefore it is reasonable to assume that the biological activity of our natural SW samples was quite high. Dissolved organic carbon (DOC) content can vary widely in Moreton Bay depending, amongst other factors, on terrestrial run-off. Approximately $14 \mathrm{~km}$ north of Redcliffe Jetty in Moreton Bay, Albert et al. (2005) measured DOC concentrations of up to $50 \mathrm{mg} \mathrm{L}^{-1}$ during a wet period 
(large run-off) in 2003. In contrast DOC concentrations were only $10-20 \mathrm{~m} \mathrm{~L}^{-1}$ during a dry period (small run-off) in 2002. Our sample collection was conducted in a relatively dry period (average monthly rainfall was low and similar to the average monthly rainfall during the Albert et al. measurements). Therefore we assume that the DOC content of our natural seawater was less than $20 \mathrm{mg} \mathrm{L}^{-1}$. Natural SW samples were refrigerated in the dark and used within 2 weeks of the collection date. They were brought to room temperature and thoroughly stirred before bubbling experiments began.

\subsection{Volatility Hygroscopicity-Tandem Differential Mobility Analyser (VH-TDMA)}

The Volatility Hygroscopicity-Tandem Differential Mobility Analyser (VH-TDMA) has been described in detail elsewhere (Fletcher et al., 2007; Johnson et al., 2004; Modini et al., 2009) and will only be discussed very briefly here. The VH-TDMA was used to measure the average diameter of initially monodisperse SSA particles as they were heated in a thermodenuder (residence time $=0.3 \mathrm{~s}$ ) from ambient to $583^{\circ} \mathrm{C}$ in temperature increments of $15-60^{\circ} \mathrm{C}$. Even after particle shrinkage occurred at higher temperatures the particles retained a monodisperse distribution. This means the average diameters before and after volatilisation could be used to calculate average volume fraction of SSA remaining $(\mathrm{V} / \mathrm{Vo})$. Volatility curves of different particle types were constructed by plotting $\mathrm{V} /$ Vo versus volatilisation temperature.

In addition, the VH-TDMA simultaneously measured the Hygroscopic Growth Factor at 90\% RH (HGF90\%) of the volatilised particles at each temperature. HGF $90 \%$ measurements of non-spherical particles taken with a (V)H-TDMA should be corrected for shape effects so they can be compared with independent measurements and theoretical predictions. The non-sphericity of dry $\mathrm{NaCl}$ particles is well described. For the range of $\mathrm{NaCl}$ particle sizes investigated in this study $(65-98 \mathrm{~nm})$ we applied a size-dependent shape correction factor that varied from 1.213-1.199 (Biskos et al., 2006). There is evidence to suggest that natural and artificial SSA particles are also non-spherical in shape and can be described with the same size-dependent shape correction factor as $\mathrm{NaCl}$ (Niedermeier et al., 2008; Wise et al., 2009). Therefore we also applied the $\mathrm{NaCl}$ shape correction factor to natural and artificial SSA particles in this study. To remove the influence of the Kelvin Effect on the HGF90\% measurements taken at different sizes they were converted to bulk HGF90\% values (i.e. where $\mathrm{aw}=\mathrm{RH}=0.9$ ) using a constant single parameter representation of hygroscopic growth (Petters and Kreidenweis, 2007). The bulk HGF90\% values are reported here. All VH-TDMA data were inverted using the TDMAinv algorithm (Gysel et al., 2009). Assuming a DMA sizing accuracy of $\pm 1 \%$ and RH uncertainty of $\pm 0.6 \%$ the theoretical uncertainty (95\% confidence level) is $\pm 3 \%$ for $\mathrm{V} /$ Vo and $\pm 3 \%$ for HGF $90 \%$.
Difference in the VH-TDMA volatility curves of natural and artificial SSA were used to investigate, and then quantify, the organic fraction of natural accumulation mode SSA. This approach is based on the assumptions that 1) natural SSA potentially contains a seawater-derived organic fraction that is not present in artificial SSA, 2) this organic fraction is more volatile than the inorganic fraction of SSA, 3) the inorganic composition of artificial and natural SWs used in these experiments is very similar, and 4) any organic impurities present in the artificial SSA were also present in the natural SSA. The third assumption was tested by using two types of artificial sea salt solution with varying inorganic composition so we could judge whether small differences in the inorganic composition of artificial SSA translated into measurable differences in the VH-TDMA volatility curves. The fourth assumption is considered a reasonable one because the precleaning process of the bubble generator was constant for all experiments and artificial SW was prepared with ultra-pure deionised water.

The advantages of using the VH-TDMA to measure the organic fraction of accumulation mode SSA are that only relatively small concentrations of particles $\left(\sim 100 \mathrm{~cm}^{-3}\right)$ are required for the analysis, total scan time is only $1-2 \mathrm{~h}$ and the lower size limit is $10 \mathrm{~nm}$. Therefore only a small bubble generator and sample of water are required (see Table 1), which reduces the chances of organic contamination. In addition, at RHs above the deliquescence point of SSA (75\%) organic components will decrease the hygroscopic growth factor of SSA (Ming and Russell, 2001). This means the HGF90\% measurements taken by the VH-TDMA can be used to confirm the conclusions drawn from the volatility measurements.

\subsection{Experimental conditions}

Table 1 lists the experiments we performed and values of important parameters compared to other studies that have utilised bubble generators. We chose to investigate whether the organic fraction of accumulation mode SSA particles depended on sample water flow rate through the bubble generator and SSA particle diameter. Water flow rate is important because if it is too low relative to the bubble flow rate (i.e. the organic source is less than the sink) then the organic content of sample water in the bubble generator could be depleted over time. The maximum water flow rate we used was $0.3 \mathrm{~L} \mathrm{~min}^{-1}$. This value was large enough to ensure that the water:air flow ratio was higher and water residence time lower then studies where large concentrations of organics have been detected in the aerosol phase. At the other extreme we performed one experiment with static water in the bubble generator that was left to bubble for $24 \mathrm{~h}$ before a VH-TDMA scan was conducted.

The influence of particle size on organic fraction was investigated because, as stated above, previous studies have shown that the organic fraction of SSA increases with decreasing particle size (Facchini et al., 2008; Keene et al., 
Table 1. Experimental parameters.

\begin{tabular}{|c|c|c|c|c|c|c|c|c|}
\hline Experiment & $\begin{array}{l}\text { Sample } \\
\text { water }\end{array}$ & $\begin{array}{l}\text { Aerosol } \\
\text { generation } \\
\text { method }\end{array}$ & $\begin{array}{l}\text { Particle } \\
\text { diameter } \\
{[\mathrm{nm}]}\end{array}$ & $\begin{array}{l}\text { Water volume } \\
\text { in bubbler } \\
{[\mathrm{L}]}\end{array}$ & $\begin{array}{l}\text { Water } \\
\text { flow rate } \\
{\left[\mathrm{Lmin}^{-1}\right]}\end{array}$ & $\begin{array}{l}\text { Bubbling } \\
\text { rate } \\
{\left[\mathrm{Lmin}^{-1}\right]}\end{array}$ & $\begin{array}{l}\text { Water:air } \\
\text { flow ratio }\end{array}$ & $\begin{array}{l}\text { Water } \\
\text { residence } \\
\text { time [s] }\end{array}$ \\
\hline $\mathrm{NaCl}_{1}$ & $\mathrm{NaCl}$ solution & Atomiser & 71 & & & & & \\
\hline $\mathrm{NaCl}_{2}$ & $\mathrm{NaCl}$ solution & Atomiser & 98 & & & & & \\
\hline $\mathrm{A}_{1}$ & Artificial SW ${ }^{a, b}$ & Bubbler & 71 & 0.2 & 0 & 0.1 & 0 & $\infty$ \\
\hline $\mathrm{A}_{2}$ & Artificial SW ${ }^{b}$ & Bubbler & 78 & 0.2 & 0 & 0.1 & 0 & $\infty$ \\
\hline $\mathrm{A}_{3}$ & Artificial SW ${ }^{\mathrm{c}}$ & Bubbler & 98 & 0.2 & 0 & 0.1 & 0 & $\infty$ \\
\hline $\mathrm{N}_{0}^{71}$ & Natural SW & Bubbler & 71 & 0.2 & 0 & 0.1 & 0 & $\infty$ \\
\hline $\mathrm{N}_{0.03}^{77}$ & Natural SW & Bubbler & 77 & 0.2 & 0.03 & 0.1 & 0.3 & 400 \\
\hline $\mathrm{N}_{0.08}^{71}$ & Natural SW & Bubbler & 71 & 0.2 & 0.08 & 0.1 & 0.8 & 150 \\
\hline $\mathrm{N}_{0.3}^{71}$ & Natural SW & Bubbler & 71 & 0.2 & 0.3 & 0.1 & 3 & 40 \\
\hline $\mathrm{N}_{0.08}^{38}$ & Natural SW & Bubbler & 38 & 0.2 & 0.08 & 0.1 & 0.8 & 150 \\
\hline $\mathrm{N}_{0.08}^{173}$ & Natural SW & Bubbler & 173 & 0.2 & 0.08 & 0.1 & 0.8 & 150 \\
\hline $\begin{array}{l}\text { Keene } \\
\text { et al. (2007) }\end{array}$ & Natural SW & Bubbler & - & 42 & 4 & 5 & 0.8 & 630 \\
\hline $\begin{array}{l}\text { Facchini } \\
\text { et al. (2008) }\end{array}$ & Natural SW & Bubbler & - & 100 & $6-7$ & 20 & 0.35 & 857 \\
\hline $\begin{array}{l}\text { Gershey } \\
(1983)\end{array}$ & Natural SW & Bubbler & - & 19 & 33.7 & 0.119 & 283 & 34 \\
\hline $\begin{array}{l}\text { Hoffman and } \\
\text { Duce (1976) }\end{array}$ & Natural SW & Bubbler & - & - & 0.2 & 0.05 & 4 & \\
\hline
\end{tabular}

${ }^{a}$ This experiment is the average of 3 almost indistinguishable repeated scans. ${ }^{b}$ Ionic mass fractions according to Seinfeld and Pandis (2006), page 444. ${ }^{c}$ Ionic mass fractions according to Niedermeier et al. (2008), Atlantic Ocean sample.

2007). Most VH-TDMA scans were performed on natural SSA particles $71-77 \mathrm{~nm}$ in mobility diameter because this was near the centre of the accumulation mode of SSA particles produced from our bubble generator, as measured by the VH-TDMA in scanning mobility particle sizer (SMPS) mode (Fig. 2). In addition scans were also performed for particles towards the lower end $(38 \mathrm{~nm})$ and upper end $(173 \mathrm{~nm})$ of the SSA accumulation mode.

\section{Results and discussion}

\subsection{VH-TDMA volatility curves}

\subsubsection{The organic fraction of 71-77 $\mathrm{nm}$ natural SSA particles}

Figure 3 displays the $\mathrm{N}_{0}^{71}, \mathrm{~N}_{0.03}^{77}, \mathrm{~N}_{0.08}^{71}$ and $\mathrm{N}_{0.3}^{71}$ volatility curves as measured by the VH-TDMA. In this notation $\mathrm{N}$ refers to natural SSA particles, the subscript number refers to the sample water flow rate through the bubble generator in $\mathrm{Lmin}^{-1}$ and the superscript number refers to the particle mobility diameter in $\mathrm{nm}$ (see Table 1 ). In addition the $\mathrm{A}_{1}, \mathrm{~A}_{2}, \mathrm{~A}_{3}, \mathrm{NaCl}_{1}$ and $\mathrm{NaCl}_{2}$ volatility curves are included for comparison (the subscript number here is simply an index). The $\mathrm{NaCl}$ particles (square markers) were very stable 


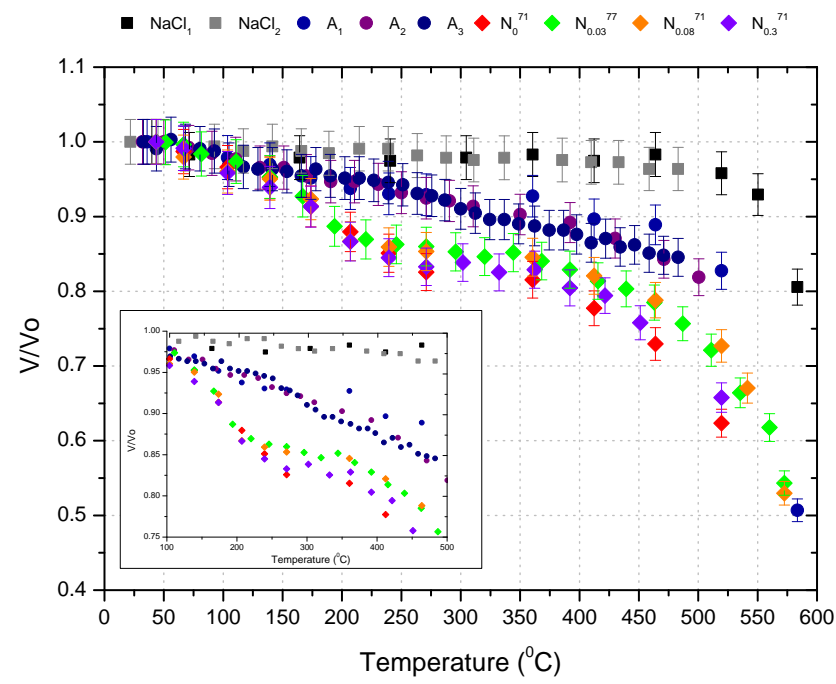

Fig. 3. Volatility curves of $\mathrm{NaCl}$ (squares), artificial SSA particles (circles) and 71-77 nm natural SSA particles (diamonds) generated using different water flow rates. Legend notation is described in text and Table 1. Error bars represent $\pm 3 \%$ measurement uncertainty in $\mathrm{V} /$ Vo. Inset graph is magnified version of main graph with error bars removed.

as volatilisation temperature was increased. A significant decrease in $\mathrm{V} / \mathrm{Vo}$ was only observed at the highest temperature obtained in these experiments, $583^{\circ} \mathrm{C}$. This sudden decrease indicated evaporation of $\mathrm{NaCl}$ had begun, which is consistent with the onset temperature for particle formation in evaporation/condensation $\mathrm{NaCl}$ aerosol generation experiments (Scheibel and Porstendörfer, 1983). The artificial SSA particles (circle markers) were more volatile than the pure $\mathrm{NaCl}$ particles. Artificial SSA V/Vo decreased fairly steadily as temperature increased so that only $82-83 \%$ of particle volume remained at $520^{\circ} \mathrm{C}$. In contrast $96 \%$ of $\mathrm{NaCl}$ particle volume remained at this temperature. The increased volatility of artificial SSA compared to $\mathrm{NaCl}$ particles could be because the evaporation or melting point of the mixture of inorganic salts was lower than the equivalent point for any pure salt in that mixture. The volatility curves of all three artificial SSA experiments agreed within the V/Vo measurement uncertainty. This indicates that small differences in the size and inorganic composition of artificial SSA does not translate into significant changes in the volatility curves, which confirms assumption number 3 of our VH-TDMA measurement approach.

The 71-77 nm natural SSA particles (diamond markers) were even more volatile than the artificial SSA particles. The natural SSA volatility curves began to diverge from the artificial SSA curves at $170^{\circ} \mathrm{C}$ (see inset, Fig. 3). A small step in the volatilisation curves was observed before they began to level out at $200^{\circ} \mathrm{C}$. Beyond this temperature the volatility curves of natural and artificial SSA became very similar in shape and appear almost parallel. The natural SSA particles were expected to contain a seawater-derived organic compo- nent not present in artificial SSA. We contend that in the temperature range $170-200^{\circ} \mathrm{C}$ the organic component of natural SSA evaporated in the VH-TDMA. Beyond this temperature the similarity of the volatility curves and point where complete evaporation begins $\left(575^{\circ} \mathrm{C}\right)$ for natural and artificial SSA is consistent with the explanation that they now have similar, predominantly inorganic composition. The average difference between the artificial and natural SSA volatility curves in the temperature range $200-500^{\circ} \mathrm{C}$ can then be taken as a measure of the average organic volume fraction of the 71-77 nm natural SSA particles. This difference was $8 \%$. The standard deviation of the difference was $2 \%$ and the theoretical uncertainty was $6 \%$ (twice the $\mathrm{V} /$ Vo measurement error). We take the larger value of $\pm 6 \%$ as the absolute error in the measured organic volume fraction of $8 \%$.

\subsubsection{Dependence of organic fraction on water flow rate through the bubble generator}

The volatility curves of $71-77 \mathrm{~nm}$ natural SSA particles generated under varying water flow rates agreed almost completely within measurement uncertainty. That is, the organic fraction of $71-77 \mathrm{~nm}$ natural SSA particles produced in our generator did not depend on water flow rate. If anything, the $\mathrm{N}_{0}^{71}$ curve lies slightly below all others. This indicates that the rate of transfer of organic material out of our bubble generator by SSA is not sufficient to deplete the organic content of a $200 \mathrm{~mL}$ sample of natural SW, even after it has been bubbling at $100 \mathrm{~mL} \mathrm{~min}^{-1}$ for $24 \mathrm{~h}$. This is consistent with calculations of the amount of organic material exported by SSA from seawater in the bubble generator. As well as the measured accumulation mode (see Fig. 2) there should have been a second super-micrometer mode in our SSA size distribution (e.g. Keene et al., 2007; Martensson et al., 2003). Therefore, we assumed a bi-modal distribution with certain properties (accumulation mode: median diameter $=0.08 \mu \mathrm{m}$, concentration $=10000 \mathrm{~cm}^{-3}$, organic mass fraction $=80 \%$; super-micrometer mode: median diameter $=4 \mu \mathrm{m}$, concentration $=200 \mathrm{~cm}^{-3}$, organic mass fraction $=10 \%$ ) and an organic density of $1.1 \mathrm{~g} \mathrm{~cm}^{-3}$ (Keene et al., 2007). Although we didn't measure such large organic fractions in this study we purposely overestimated them for this calculation. Under these assumptions and the conditions of our bubbling experiments only $2 \times 10^{-4} \mathrm{~g} \mathrm{day}^{-1}$ of organic material would be exported by SSA from our sample water. If we assume the organic content of our $200 \mathrm{~mL}$ sample of seawater was only $1 \mathrm{mg} \mathrm{L}^{-1}$, it would take $23 \mathrm{~h}$ of SSA generation to deplete all the organics in the water. If we assume the seawater organic concentration was $10 \mathrm{mg} \mathrm{L}^{-1}$, full depletion would take $234 \mathrm{~h}$. The fact that organics were not depleted in our generator after bubbling for $24 \mathrm{~h}$ suggests that the organic content of our sample water was greater than $1 \mathrm{mg} \mathrm{L}^{-1}$, or that we have overestimated the number and organic fraction of super-micrometer SSA particles in this calculation. 


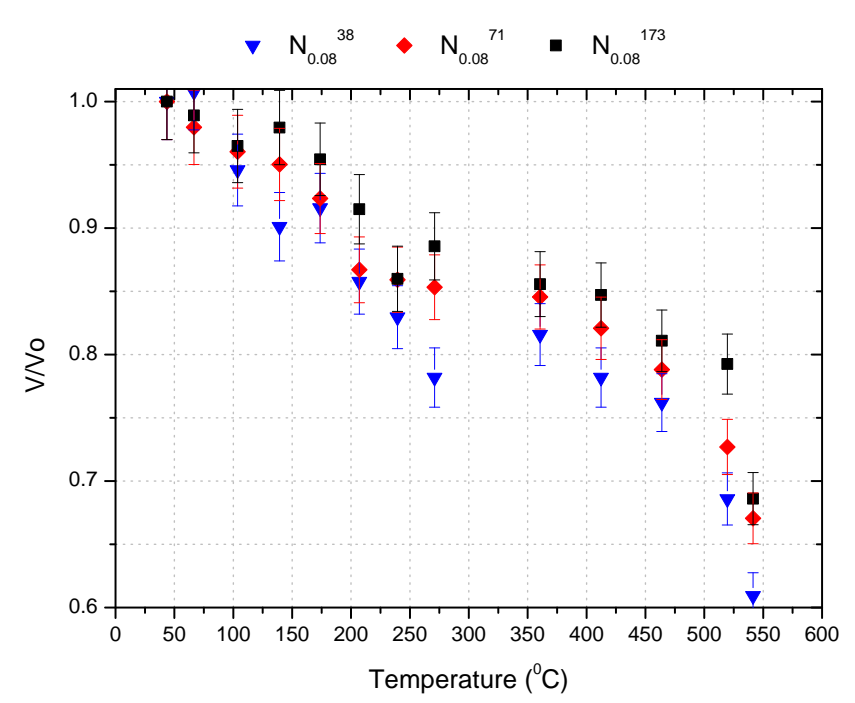

Fig. 4. Volatility curves of $38 \mathrm{~nm}$ (upside down triangles), $71 \mathrm{~nm}$ (diamonds) and $173 \mathrm{~nm}$ (squares) natural SSA particles. Legend notation is described in text and Table 1 . Error bars represent $\pm 3 \%$ measurement uncertainty in $\mathrm{V} / \mathrm{Vo}$.

\subsubsection{Dependence of organic fraction on particle size in the range $38-173 \mathrm{~nm}$}

Figure 4 displays the $38 \mathrm{~nm}\left(\mathrm{~N}_{0.08}^{38}\right), 71 \mathrm{~nm}\left(\mathrm{~N}_{0.08}^{71}\right)$, and $173 \mathrm{~nm}\left(\mathrm{~N}_{0.08}^{173}\right)$ volatility curves. It appears that volatility increased slightly with decreasing particle size. In the temperature range $200-500^{\circ} \mathrm{C}$ where it is expected that the organic fraction of the particles has evaporated the average difference ( \pm 1 standard deviation) between the $173 \mathrm{~nm}$ and $38 \mathrm{~nm}$ curves is $6 \pm 3 \%$. The average difference between the $173 \mathrm{~nm}$ and $71 \mathrm{~nm}$ curves and the $71 \mathrm{~nm}$ and $38 \mathrm{~nm}$ curves in the same range is $2 \pm 2 \%$ and $3 \pm 2 \%$, respectively. However, these volatility differences could be due to differences in particle size as well as composition (organic fraction). Therefore these values do not represent the difference in organic volume fraction for the different particles sizes. Rather they overestimate these fractions by an unknown amount equal to the percentage change in $\mathrm{V} / \mathrm{Vo}$ due to the change in initial particle size. Taking this into account and the fact that the theoretical uncertainty in the calculation of organic volume fraction is $6 \%$, we conclude that the organic fraction of natural SSA particles did not vary significantly with particle mobility diameter in the range $38-173 \mathrm{~nm}$.

\subsection{Hygroscopic growth factor measurements}

To improve the representation of the shape- and Kelvincorrected bulk HGF90\% data all of the measurements were first categorised as $\mathrm{NaCl}$, artificial SSA or natural SSA (71$77 \mathrm{~nm}$ ) particles. Then a number of measurements were averaged at specific temperature values to obtain average HGF90\% for each particle type as a function of temper-

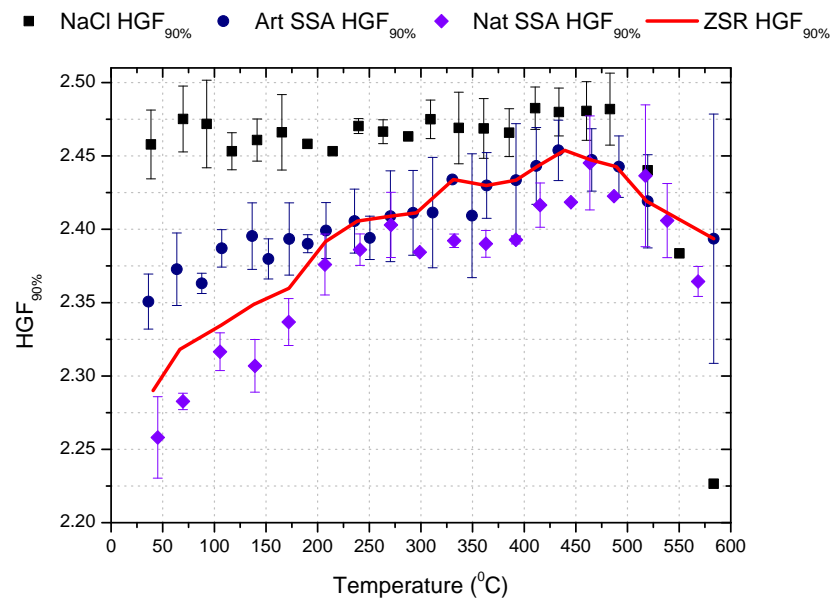

Fig. 5. Shape- and Kelvin-corrected bulk HGF90\% values for $\mathrm{NaCl}$ (squares), artificial SSA (circles) and natural SSA (diamonds) particles as a function of volatilisation temperature. Each data point represents an average of a number of measurements and error bars represent \pm 1 standard deviation. Measurement uncertainty in HGF90\% was $\pm 3 \%$. Also included is the ZSR predicted HGF90\% curve (solid red line). See text for details on the calculation of this curve.

ature. These averages are plotted in Fig. 5. At ambient temperature $\mathrm{NaCl} \mathrm{HGF} 90 \%$ was $2.46 \pm 0.02$. Artificial SSA HGF90\% was $4.4 \%$ lower at $2.35 \pm 0.02$. These values both agree well with theoretical predictions of $\mathrm{NaCl}$ and artificial SSA HGF90\% (e.g. Ming and Russell, 2001). Natural SSA HGF90\% was $3.9 \%$ lower than artificial SSA (8.1\% lower than $\mathrm{NaCl}$ ) at $2.26 \pm 0.02$.

It is instructive to observe how HGF90\% for each particle type varied as a function of temperature. $\mathrm{NaCl} \mathrm{HGF} 90 \%$ was fairly constant until particle evaporation began at the highest temperatures. At this point $\mathrm{NaCl} \mathrm{HGF} 90 \%$ decreased. Artificial SSA HGF90\% continually increased with increasing volatilisation temperature. Natural SSA HGF90\% was below artificial SSA HGF90\% up to a volatilisation temperature of $170^{\circ} \mathrm{C}$. At this temperature the organic component of the natural SSA particles began evaporating (see Fig. 3). Coinciding with this the HGF90\% curve started approaching the artificial SSA HGF90\% curve. At temperatures above $206^{\circ} \mathrm{C}$ the artificial and natural HGF90\% curves agreed almost completely within experimental variation. The shapes of the two curves were even very similar.

Under the ZSR approximation (Chen et al., 1973; Stokes and Robinson, 1966) it is possible to investigate whether the difference in the natural and artificial SSA HGF90\% curves at lower temperatures is consistent with the volume fraction of organics in the natural SSA particles as calculated from the volatility data (see Sect. 3.1). When making the ZSR approximation it is assumed that the individual components of an internally mixed particle do not interact with each other and therefore they uptake water independently. In practice this 
means that the HGF of a mixed particle can be calculated by the volume-fraction-weighted sum of the HGF's of individual components in that particle. We can use this assumption to predict $\mathrm{HGF} 90 \%$ for our natural SSA particles assuming they are a binary mixture of an organic and inorganic (sea salt) component. For input into the ZSR approximation we use our measured organic volume fraction as a function of temperature, our measured bulk HGF90\% of artificial SSA as a function of temperature and assume a bulk HGF90\% for the organic component of 1 . This leads to a ZSR predicted HGF90\% curve which is plotted in Fig. 5. There is generally good agreement between the ZSR predicted and measured natural SSA HGF90\% curves. At temperatures less than $20{ }^{\circ} \mathrm{C}$ the ZSR predicted curve only slightly overestimates the measurements. At temperatures greater than $200^{\circ} \mathrm{C}$ the ZSR predicted HGF90\% curve equals the artificial HGF90\% curve because it is assumed that all organics have evaporated from the natural SSA particles and organic volume fraction is set to 0 (Fig. 3).

In summary, the HGF90\% data are consistent with the conclusions drawn from the volatility data. Namely, that our natural SSA particles had a minor organic component that evaporated over the temperature range $170-200^{\circ} \mathrm{C}$. After evaporation the natural and artificial SSA particles had similar, predominantly inorganic composition.

\subsection{Implications}

We have measured an organic volume fraction of $8 \pm 6 \%$ for $71-77 \mathrm{~nm}$ natural SSA particles that were generated from samples of coastal seawater that most likely had high organic content. Note that this means aerosol-phase organics were still enriched by tens or hundreds of times relative to the sample water, depending on the exact concentration of organics in the sample water. Assuming an organic density of $1.1 \mathrm{~g} \mathrm{~cm}^{-3}$ (Keene et al., 2007) our measurement corresponds to an organic mass fraction of only $4 \%$. We also investigated the organic fractions of 38 and $173 \mathrm{~nm}$ natural SSA particles and found these did not differ significantly from the organic fraction of 71-77 $\mathrm{nm}$ particles. In comparison, Keene et al. measured an organic mass fraction of $80 \%$ for $130 \mathrm{~nm}$ (GMD) natural SSA particles in similar bubbling experiments. Facchini et al. measured an organic fraction of $77 \pm 5 \%$ for $125-250 \mathrm{~nm}$ natural SSA particles. These findings have led to the expectation that accumulation mode SSA particles generated from biologically active or organic-rich seawaters are predominantly organic. Our results suggest that this is not always the case.

Hygroscopicity measurements in the literature also provide indirect evidence that accumulation mode SSA particles often contain only a minor organic fraction. Sea salt aerosol (i.e. purely inorganic) is very hygroscopic. If a major, non-hygroscopic organic fraction is present in SSA it will significantly decrease the hygroscopicity of that aerosol. For example an SSA particle consisting of $20 \%$ sea salt
$(\mathrm{HGF} 90 \%=2.35)$ and $80 \%$ organics $(\mathrm{HGF} 90 \%=1)$ will have HGF90\% $=1.5$ according to the ZSR approximation. A few studies have reported HGF's above deliquescence RH for accumulation mode natural SSA particles that are only slightly below $(<10 \%)$ corresponding $\mathrm{NaCl}$ or sea salt HGF's (Niedermeier et al., 2008; Sellegri et al., 2008; Nilsson (2007) referenced in Switelicki et al., 2008). This suggests the natural SSA particles investigated in these studies did not contain large organic fractions. In a very recent study Herich et al. (2009) detected an organic component in both fresh and aged $260 \mathrm{~nm}$ SSA particles at a remote continental site in the arctic circle in northern Sweden. The authors found that SSA organic content did not correlate with SSA hygroscopicity. This implies that the organic component only formed a very minor fraction of total SSA mass, because changes in the amount of organics present had no effect on particle hygroscopicity. Although these studies do not report measurements (e.g. organic content, biological activity) of the source water from which aerosols were generated, they nevertheless suggest that accumulation mode SSA frequently contains only a minor organic fraction.

Discrepancies between the different studies could be related to not only the amount of organics present in the source waters used in each experiment, but also the composition and surface-active nature of those organics. For example Facchini et al. (2008) conducted their measurements with organic-rich Atlantic Ocean water collected during a plankton bloom. The Keene et al. (2007) results were obtained using seawater collected from a Bermuda passage (Ferry Reach). Measurements indicated the water was representative of the surrounding oligotrophic open ocean surface water. Our measurements were conducted with organic-rich seawater, but this time collected at a coastal site significantly affected by terrestrial run-off. The difference in the composition of organics (anthropogenic or biogenic, coastal or open ocean) may affect how enriched they become in the aerosol phase. We are not aware of any studies that have examined the relationship between seawater type and SSA organic fraction. Therefore it is not clear what effect, if any, the use of coastal as opposed to ocean seawater had on the SSA organic fraction measured in this study.

In addition to seawater type, methodological differences could have potentially contributed to some of the difference between the results of this study and the results of the Keene et al. and Facchini et al. studies. The two previous studies were conducted with freshly-collected seawater while in this study seawater was stored in a dark refrigerator for up to 2 weeks. The properties of seawater organics may have changed during this storage time which could have affected their transfer to the aerosol phase. However, we note that no significant differences were observed between scans completed at different times during the 2 week measurement period. Therefore any artefacts due to storage are likely to be minimal. The bubble generator employed in this study was also far smaller than those used in previous studies (see water 
volumes in Table 1). While this reduced the risk of external organic contamination, it also meant our generator had a high surface to volume ratio. As seawater flowed bottom-to-top in the generator organics potentially adsorbed to the walls thereby reducing the amount of organics eventually transferred to the aerosol. This potential loss mechanism was not quantified or estimated. We do not believe that these methodological differences can account for the order of magnitude difference between our measured accumulation mode SSA organic fraction and the fractions measured in the Keene et al. and Facchini et al. studies.

O'Dowd et al. (2008) have developed a combined organicinorganic sub-micron sea spray source function for modelling purposes. One input into this source function is the organic mass fraction of sub-micron SSA as a function of chl- $a$ concentration, which was derived from ambient measurements conducted at Mace Head, Ireland. This function saturates at $90 \%$ organic mass fraction for chl- $a$ concentrations above $1.27 \mathrm{mg} \mathrm{m}^{-3}$. Chl- $a$ concentration was at least this high, and probably higher, in the seawater used in this study. However, the organic mass fraction of accumulation mode SSA was only $4 \%$. This suggests that the sub-micron SSA organic fractions predicted by the O'Dowd et al. source function may be significant overestimates of the true values in regions other than off the coast of Mace Head.

These considerations point to the need for further independent, size-resolved measurements of the organic fraction of SSA produced from a variety of different seawaters. Based on the conflicting studies, it seems that there may be some additional properties of seawater (e.g. organic composition, surface-active nature of organics) that control how much organic material is transported from water to the aerosol phase during the bubble bursting process. In addition, our results suggest that if these experiments are conducted with bubble generators, it may not be necessary to cycle water through the generator to maintain a fresh supply of seawater-organics. Bubble-generated SSA did not deplete the organic content of static seawater in our bubble generator over a $24 \mathrm{~h}$ period.

\section{Conclusions}

A bubble generator was constructed and used to produce SSA particles from samples of coastal seawater collected from Moreton Bay on the east coast of Australia. Chlorophyll- $a$ measurements conducted close to the sampling point on either side of the collection date indicate that the samples were biologically active and had high organic content. A VHTDMA was used to investigate the organic fraction of accumulation mode SSA particles produced from bubbling the seawater in the generator. The volatility and hygroscopic data collected by the VH-TDMA were in good agreement with each other, and suggested that the natural SSA particles contained an organic component that evaporated in the range $170-200^{\circ} \mathrm{C}$. A comparison between the volatil- ity curves of artificial and natural SSA particles was used to quantify the organic fraction of $71-77 \mathrm{~nm}$ natural SSA particles at $8 \pm 6 \%$. This measurement is an order of magnitude below comparable previous measurements of the organic fraction of accumulation mode SSA. At room temperature we measured shape- and Kelvin-corrected growth factors at $90 \% \mathrm{RH}$ of $2.46 \pm 0.02$ for $\mathrm{NaCl}, 2.35 \pm 0.02$ for artifical SSA and $2.26 \pm 0.02$ for natural SSA particles. We reiterate that our results apply to accumulation mode SSA generated from coastal as opposed to open ocean seawater.

Acknowledgements. This work was funded by the International Laboratory for Air Quality and Health. The authors gratefully acknowledge the South East Queensland Healthy Waterways Partnership (www.healthywaterways.org) for provision of the chlorophyll a data for Moreton Bay.

Edited by: A. Nenes

\section{References}

Albert, S., O’Neil, J. M., Udy, J. W., Ahern, K. S., O'Sullivan, C. M., and Dennison, W. C.: Blooms of the cyanobacterium Lyngbya majuscula in coastal Queensland, Australia: disparate sites, common factors, Mar. Pollut. Bull., 51, 428-437, 2005.

Andreae, M. O. and Rosenfeld, D.: Aerosol-cloud-precipitation interactions, Part 1. The nature and sources of cloud-active aerosols, Earth-Sci. Rev., 89, 13-41, 2008.

Barker, D. R. and Zeitlin, H.: Metal-ion concentrations in seasurface microlayer and size-separated atmospheric aerosol samples in Hawaii, J. Geophys. Res., 77(27), 5076-5086, 1972.

Bigg, E. K. and Leck, C.: The composition of fragments of bubbles bursting at the ocean surface, J. Geophys. Res., 113, D11209, doi:10.1029/2007JD009078, 2008.

Biskos, G., Russell, L. M., Buseck, P. R., and Martin, S. T.: Nanosize effect on the hygroscopic growth factor of aerosol particles, Geophys. Res. Lett., 33, L07801, doi:10.1029/2005GL025199, 2006.

Blanchard, D. C.: Sea-to-air transport of surface active material, Science, 146, 396-397, doi:10.1126/science.146.3642.396, 1964.

Blanchard, D. C.: The ejection of drops from the sea their enrichment with bacteria and other materials: A review, Estuaries, 12, 127-137, 1989.

Chen, H., Sangster, J., Teng, T. T., and Lenzi, F.: A general method of predicting the water activity of ternary aqueous solutions from binary data, Can. J. Chem. Eng., 51, 234-241, 1973.

Clarke, A. D., Owens, S. R., and Zhou, J.: An ultrafine sea-salt flux from breaking waves: implications for cloud condensation nuclei in the remote marine atmosphere, J. Geophys. Res., 111, D06202, doi:10.1029/2005JD006565, 2006.

Eaton, A. D., Clesceri, L. S., Rice, E. W., and Greenberg, A. E.: Standard methods for the examination of water and wastewater, American Public Health Association, American Water Works Association, Water Environment Federation, Section 2520B, 2005. 
Facchini, M. C., Rinaldi, M., Decesari, S., Carbone, C., Finessi, E., Mircea, M., Fuzzi, S., Ceburnis, D., Flanagan, R., Nilsson, E. D., de Leeuw, G., Martino, M., Woeltjen, J., and O'Dowd, C. D.: Primary submicron marine aerosol dominated by insoluble organic colloids and aggregates, Geophys. Res. Lett., 35, L17814, doi:10.1029/2008GL034210, 2008.

Fletcher, C. A., Johnson, G. R., Ristovski, Z. D., and Harvey, M.: Hygroscopic and volatile properties of marine aerosol observed at Cape Grim during the P2P campaign, Environ. Chem., 4, 162171, 2007.

Gershey, R. M.: Characterization of seawater organic matter carried by bubble-generated aerosols, Limnol. Oceanogr., 28, 309-319, 1983.

Gysel, M., McFiggans, G. B., and Coe, H.: Inversion of tandem differential mobility analyser (TDMA) measurements, J. Aerosol Sci., 40, 134-151, 2009.

Herich, H., Kammermann, L., Friedman, B., Gross, D. S., Weingartner, E., Lohmann, U., Spichtinger, P., Gysel, M., Baltensperger, U., and Cziczo, D. J.: Subarctic atmospheric aerosol composition: 2. Hygroscopic growth properties, J. Geophys. Res., 114, D13204, doi:10.1029/2008JD011574, 2009.

Hoffman, E. J. and Duce, R. A.: The organic carbon content of marine aerosols collected on Bermuda, J. Geophys. Res., 79(30), 4474-4477, 1974.

Hoffman, E. J. and Duce, R. A.: Factors influencing the organic carbon content of marine aerosols: a laboratory study, J. Geophys. Res., 81(21), 3667-3670, 1976.

Hunter, K. A.: Chemistry of the Sea-Surface Microlayer, in: The Sea Surface and Global Change, edited by: Liss, P. S. and Duce, R. D., Cambridge University Press, Cambridge, UK, 287321, 1997.

Johnson, G. R., Ristovski, Z., and Morawska, L.: Method for measuring the hygroscopic behaviour of lower volatility fractions in an internally mixed aerosol, J. Aerosol Sci., 35, 443-455, 2004.

Keene, W. C., Maring, H., Maben, J. R., Kieber, D. J., Pszenny, A. A. P., Dahl, E. E., Izaguirre, M. A., Davis, A. J., Long, M. S., Zhou, X., Smoydzin, L., and Sander, R.: Chemical and physical characteristics of nascent aerosols produced by bursting bubbles at a model air-sea interface, J. Geophys. Res., 112, D21202, doi:10.1029/2007JD008464, 2007.

Liss, P. S. and Duce, R. D.: The sea surface and global change, Cambridge University Press, Cambridge, UK, 1997.

Martensson, E. M., Nilsson, E. D., de Leeuw, G., Cohen, L. H., and Hansson, H. C.: Laboratory simulations and parameterization of the primary marine aerosol production, J. Geophys. Res., 108(D9), 4297, doi:10.1029/2002JD002263, 2003.

Ming, Y. and Russell, L. M.: Predicted hygroscopic growth of sea salt aerosol, J. Geophys. Res., 106(D22), 28259-28274, 2001.

Modini, R. L., Ristovski, Z. D., Johnson, G. R., He, C., Surawski, N., Morawska, L., Suni, T., and Kulmala, M.: New particle formation and growth at a remote, sub-tropical coastal location, Atmos. Chem. Phys., 9, 7607-7621, 2009,

http://www.atmos-chem-phys.net/9/7607/2009/.

Moore, R. H., Ingall, E. D., Sorooshian, A., and Nenes, A.: Molar mass, surface tension, and droplet growth kinetics of marine organics from measurements of CCN activity, Geophys. Res. Lett., 35, L07801, doi:10.1029/2008g1033350, 2008.

Niedermeier, D., Wex, H., Voigtländer, J., Stratmann, F., Brüggemann, E., Kiselev, A., Henk, H., and Heintzenberg, J.:
LACIS-measurements and parameterization of sea-salt particle hygroscopic growth and activation, Atmos. Chem. Phys., 8, 579590, 2008, http://www.atmos-chem-phys.net/8/579/2008/.

O'Dowd, C. D. and Smith, M. H.: Physicochemical properties of aerosols over the northeast Atlantic: evidence for wind-speedrelated submicron sea-salt aerosol production, J. Geophys. Res., 98(D1), 1137-1149, 1993.

O’Dowd, C. D., Smith, M. H., Consterdine, I. E., and Lowe, J. A.: Marine aerosol, sea-salt, and the marine sulphur cycle: a short review, Atmos. Environ., 31, 73-80, 1997.

O’Dowd, C. D., Langmann, B., Varghese, S., Scannell, C., Ceburnis, D., and Facchini, M. C.: A combined organic-inorganic sea-spray source function, Geophys. Res. Lett., 35, L01801, doi:10.1029/2007GL030331, 2008.

Oppo, C., Bellandi, S., Degli Innocenti, N., Stortini, A. M., Loglio, G., Schiavuta, E., and Cini, R.: Surfactant components of marine organic matter as agents for biogeochemical fractionation and pollutant transport via marine aerosols, Mar. Chem., 63, 235-253, 1999.

Petters, M. D. and Kreidenweis, S. M.: A single parameter representation of hygroscopic growth and cloud condensation nucleus activity, Atmos. Chem. Phys., 7, 1961-1971, 2007,

http://www.atmos-chem-phys.net/7/1961/2007/.

Pierce, J. R. and Adams, P. J.: Global evaluation of CCN formation by direct emission of sea salt and growth of ultrafine sea salt, J. Geophys. Res., 111, D06203, doi:10.1029/2005JD006186, 2006.

Randles, C. A., Russell, L. M., and Ramaswamy, V.: Hygroscopic and optical properties of organic sea salt aerosol and consequences for climate forcing, Geophys. Res. Lett., 31, L16108, doi:10.1029/2004GL020628, 2004.

Scheibel, H. G. and Porstendörfer, J.: Generation of monodisperse $\mathrm{Ag}$ - and NaCl-aerosols with particle diameters between 2 and 300 nm, J. Aerosol Sci., 14, 113-126, 1983.

Seinfeld, J. H. and Pandis, S. N.: Atmospheric Chemistry and Physics: From Air Pollution to Climate Change, 2nd ed., Wiley, Hoboken, NJ, USA, p. 444, 2006.

Sellegri, K., O'Dowd, C. D., Yoon, Y. J., Jennings, S. G., and de Leeuw, G.: Surfactants and submicron sea spray generation, J. Geophys. Res., 111, D22215, doi:10.1029/2005JD006658, 2006.

Sellegri, K., Villani, P., Picard, D., Dupuy, R., O’Dowd, C., and Laj, P.: Role of the volatile fraction of submicron marine aerosol on its hygroscopic properties, Atmos. Res., 90, 272-277, 2008.

Spiel, D. E.: On the births of jet drops from bubbles bursting on water surfaces, J. Geophys. Res., 100(C3), 4995-5006, 1995.

Spiel, D. E.: On the births of film drops from bubbles bursting on seawater surfaces, J. Geophys. Res., 103(C11), 24907-24918, 1998.

Stokes, R. H. and Robinson, R. A.: Interactions in aqueous nonelectrolyte solutions: I. Solute-solvent equilibria, J. Phys. Chem., 70, 2126-2130, 1966.

Swietlicki, E., Hansson, H.-C., Hämeri, K., Svenningsson, B., Massling, A., McFiggans, G. B., Mcmurry, P. H., Petäjä, T., Tunved, P., Gysel, M., Topping, D., Weingartner, E., Baltensperger, U., Rissler, J., Wiedensohler, A., and Kulmala, M.: Hygroscopic properties of submicrometer atmospheric aerosol particles measured with H-TDMA instruments in various envi- 
ronments: a review, Tellus B, 60, 432-469, 2008.

Tyree, C. A., Hellion, V. M., Alexandrova, O. A., and Allen, J. O.: Foam droplets generated from natural and artificial seawaters, J. Geophys. Res., 112, D12204, doi:10.1029/2006JD007729, 2007.

Wise, M. E., Freney, E. J., Tyree, C. A., Allen, J. O., Martin, S. T., Russell, L. M., and Buseck, P. R.: Hygroscopic behavior and liquid-layer composition of aerosol particles generated from natural and artificial seawater, J. Geophys. Res., 114, D03201, doi:10.1029/2008JD010449, 2009.
Zhou, X., Davis, A. J., Kieber, D. J., Keene, W. C., Maben, J. R., Maring, H., Dahl, E. E., Izaguirre, M. A., Sander, R., and Smoydzyn, L.: Photochemical production of hydroxyl radical and hydroperoxides in water extracts of nascent marine aerosols produced by bursting bubbles from Sargasso seawater, Geophys. Res. Lett., 35, L20803, doi:10.1029/2008GL035418, 2008. 